\title{
Katarzyna Wira-Światkowska
}

Uniwersytet Łódzki

\section{Powstanie polskiego czasopiśmiennictwa pedagogicznego przeznaczonego dla wychowawczyń przedszkoli}

Czasopiśmiennictwo pedagogiczne w Europie swoimi początkami sięga wieku XVIII. Wtedy to znacząco wzrosło zainteresowanie problemami oświaty i wychowania oraz ideami pedagogicznymi, a w konsekwencji pojawiło się przekonanie o pilnej potrzebie doskonalenia moralnego za pośrednictwem kształcenia umysłów. Pogląd ten znalazł odbicie $m$. in. w tworzonych w epoce Oświecenia czasopismach moralnych, mających na celu właśnie wychowywanie społeczeństw. W Polsce czasopismem o takim charakterze był wydawany w latach 1765-1784 „Monitor”, redagowany przez Franciszka Bohomolca ${ }^{1}$. Ojczyzną właściwych czasopism pedagogicznych były Niemcy i Francja. Na przełomie XVIII i XIX w. pojawiły się tam pierwsze typowe czasopisma pedagogiczne, francuski „Journal de l'Instruction” w roku 1793 i niemieckie „Deutscher Schulfreud”, „Bibliothek für Pädagogik” oraz „Schulwesen und die gesamte pädagogische Literatur" w roku $1801^{2}$. W miarę rozwoju szkolnictwa publicznego, wzrostu stanu nauczycielskiego oraz tworzenia się zrzeszeń nauczycielskich prasa pedagogiczna rozwijała się coraz intensywniej. Znaczący wpływ na rozwój ruchu wydawniczego w całej Europie miały także hasła „Nowego Wychowania".

W Polsce powstanie czasopiśmiennictwa pedagogicznego przypada na czas nieco późniejszy. Podobnie jak w wielu innych dziedzinach życia społecznego, stosunki polityczne w okresie zaborów utrudniały postęp w zakresie rozwoju szkolnictwa, myśli pedagogicznej, a tym samym także czasopiśmiennictwa pedagogicznego. Jakkolwiek pierwsze polskie czasopisma pedagogiczne zaczęły pojawiać się już w tym okresie, to rozwój ich przebiegał nierównomiernie, w zależności od zmiennej sytuacji politycznej w każdym z zaborów. Jak pisał Stefan Truchim:

\footnotetext{
${ }^{1}$ S. Truchim, Polskie czasopisma pedagogiczne, „Oświata i Wychowanie” 1932, nr 8, s. 763.

${ }^{2}$ J. Jarowiecki, Czasopisma pedagogiczne w Polsce, [hasło w:] Encyklopedia pedagogiczna, red. W. Pomykało, Warszawa 1993, s. 78-79.
} 
Nierównomierny rozwój czasopiśmiennictwa pedagogicznego przypisać należy brakowi własnego państwa i wynikłym z tego powodu utrudnieniom stawianym przez rządy zaborcze, rozwijaniu zagadnień wychowania polskiego dziecka, które zależnie od zaboru, rządy pragnęły uczynić Rosjaninem, Prusakiem czy Austriakiem ${ }^{3}$.

W związku ze specyfiką tego okresu, czasopisma pedagogiczne oprócz funkcji popularyzowania wiedzy pedagogicznej wśród nauczycieli i rodziców, pełniły również funkcję kształtowania i utrzymywania świadomości narodowej w warunkach niewoli. Za pierwsze polskie czasopismo pedagogiczne uznawany jest ukazujący się nieregularnie w latach 1824, 1826-1827, 1830 - „Rocznik Instytutów Religijnych i Edukacyjnych w Królestwie Polskim”4. Jednak w piśmie tym, jako organie administracji szkolnej, zamieszczano głównie informacje o organizacji ówczesnych szkół oraz działaczach oświatowych, zalecanych podręcznikach, nie poruszano zaś teoretycznych zagadnień pedagogicznych ${ }^{5}$. Czasopismem, które w całości poświęcone było pedagogice i wychowaniu narodowemu, była dopiero „Szkoła Polska” wydawana w latach 1849-1853 w Poznaniu, pod redakcją Ewarysta Estkowskiego ${ }^{6}$. Pismo to nawiazzywało do ideałów Komisji Edukacji Narodowej, zaznaczając kwestie powinności nauczycielstwa polskiego, znaczenia i roli wychowania szkolnego i domowego oraz zagadnienia powiązań między oświatą a życiem społeczno-politycznym. W roku 1882 zaczął ukazywać się, z inicjatywy Eugeniusza Babickiego, „Przegląd Pedagogiczny" - pierwsze w Królestwie Polskim wydawnictwo ciagłe, poświęcone teorii i praktyce nauczania w domu i w szkole. W Galicji pierwsze czasopismo pedagogiczne, zatytułowane „Szkoła”, powstało w roku 1868. Obydwa te czasopisma wydawane były aż do wybuchu II wojny światowej. Stan polskiej prasy pedagogicznej $\mathrm{w}$ porównaniu $\mathrm{z}$ innymi krajami europejskimi przedstawiał się skromnie, jednak kiedy uwzględni się trudne warunki wynikające z niewoli, problemy finansowe wydawców, konkurencję czasopism niemieckich i rosyjskich popieranych przez władze szkolne, należy stwierdzić, że uczyniono w tej dziedzinie wiele, a sytuacja stale ulegała poprawie. W ostatnim roku przed wybuchem I wojny światowej wychodziły na ziemiach polskich 34 tytuły czasopism pedagogicznych. Okres wojny przyniósł dalsze ożywienie w tej kwestii, powstało wówczas kolejnych 13 tytułów ${ }^{7}$.

Wielki rozkwit działalności wydawniczej w zakresie czasopiśmiennictwa pedagogicznego nastapił $\mathrm{w}$ okresie dwudziestolecia międzywojennego i był on nieporównywalny z żadnym innym okresem historycznym $\mathrm{w}$ dziejach polskiej

\footnotetext{
${ }^{3}$ S.Truchim, Polskie czasopisma..., s. 763.

${ }^{4}$ Tamże.

${ }^{5}$ S. Możdżeń, Bibliografia polskich czasopism pedagogicznych do 1979 roku, Kielce 1981,

${ }^{6}$ Tamże.

${ }^{7}$ Tamże, s. 20.
} s. 10 . 
oświaty. Ogólna liczba tytułów, łącznie z dziennikami urzędowymi administracji szkolnej i czasopismami wydawanymi u nas w języku niemieckim, ukraińskim, litewskim i żydowskim, przekraczała liczbę trzystu ${ }^{8}$. Niektóre z nich dość długo utrzymywały się na rynku wydawniczym, wiele ukazywało się nieregularnie i przez krótki okres, zazwyczaj o ich sytuacji decydowały czynniki finansowe. Tylko 61 czasopism istniało dłużej niż 10 lat, w tej liczbie było 15 wydawanych przez całe dwudziestolecie ${ }^{9}$. Najlepszy okres dla rozwoju publicystyki oświatowej to lata $1920-1935$, był to czas

największego ożywienia w zakresie ilościowego i jakościowego rozwoju periodyków pedagogicznych. W tym też okresie obserwujemy najwyższy wzrost nakładów i prenumeratorów związkowej prasy pedagogicznej, największe nasilenie czytelnictwa oraz zainteresowań sprawami wydawniczymi $^{10}$.

Dość pokaźną, jak na warunki polskie, liczbę czasopism pedagogicznych Wiktor Czerniewski tłumaczy z jednej strony ruchliwością ośrodków prowincjonalnych, $\mathrm{z}$ drugiej zaś strony istniejącym u nas rozbiciem ruchu nauczycielskiego, nie tylko ze względów narodowościowych lub ideologicznych, ale również z powodów organizacyjnych ${ }^{11}$.

Międzywojenne periodyki pedagogiczne, jako podstawowy w tym okresie środek przekazu aktualnego stanu wiedzy i doświadczeń dydaktyczno-wychowawczych, przyczyniały się do rozwoju polskiej myśli pedagogicznej, likwidując w znacznym stopniu opóźnienie, jakie polska oświata i szkolnictwo w latach zaborów miały w stosunku do innych krajów europejskich. Upowszechniały dorobek polskiej i światowej myśli pedagogicznej, odgrywały ważną rolę w kształceniu i dokształcaniu zawodowym nauczycieli, dążyły do podnoszenia świadomości pedagogicznej społeczeństwa. Często służyły radą i pomocą praktyczną zarówno nauczycielom, jak i rodzicom. Jak pisze Maria J. Żmichrowska:

najważniejszym walorem międzywojennego czasopiśmiennictwa pedagogicznego była jego silna więź z pedagogicznym zapleczem naukowym, umiejętna współpraca z ówczesnymi autorytetami, szybkie i sprawne informowanie o postępie myśli pedagogicznej, popularyzowanie nowoczesnych rozwiązań dydaktycznych ${ }^{12}$.

\footnotetext{
${ }^{8}$ W. Czerniewski, Czasopiśmiennictwo w Polsce okresu międzywojennego, „Nowa Szkoła” 1968, nr 10-11, s. 104.

${ }^{9}$ Tamże.

${ }^{10}$ Rola prasy pedagogicznej w życiu nauczyciela, ,, Głos Nauczycielski” 1934, nr 37, s. 858.

${ }^{11}$ W. Czerniewski, Czasopiśmiennictwo w Polsce..., s. 104.

${ }^{12}$ M. J. Żmichrowska, Wybrane zagadnienia czasopism pedagogicznych $w$ Polsce $w$ latach 1918-1939, Olsztyn 1992, s. 21.
} 
W latach międzywojennych, oprócz zwiększania się liczby czasopism ogólnopedagogicznych, nastąpił również znaczący rozwój czasopiśmiennictwa specjalistyczno-pedagogicznego i przedmiotowo-metodycznego. Na szczególną uwagę zasługują powstałe $\mathrm{w}$ tym czasie czasopisma pedagogiczne przeznaczone dla nauczycieli przedszkoli. Powstawanie tego typu periodyków wiązało się niewątpliwie z rozwijającą się wówczas pedagogiką przedszkolną. Dotąd problematyka przedszkolna pojawiała się sporadycznie na łamach różnorodnej prasy polskiej. Jedną z najwcześniejszych prac poruszających tę tematykę była zamieszczona w roku 1842 w czasopiśmie „Biblioteka Warszawska” obszerna rozprawa Augusta Cieszkowskiego O ochronach wiejskich, w której autor m. in. przedstawił pierwszą polską koncepcję zawodowego kształcenia opiekunek małych dzieci ${ }^{13}$. Problematykę wychowania dziecka w wieku przedszkolnym podnosiły w okresie zaborów także takie czasopisma, jak „Opiekun Domowy”, „Bluszcz”, „Ziemianka”, „Ruch Pedagogiczny”, „Czasopismo Pedagogiczne”, „Prawda”, „Niwa”, „Nowe Tory”, „Zdrowie”, „Kronika Rodzinna”, „Dziecko” „Przegląd Tygodniowy”, „Świat Kobiecy”, „, Polski Łan”, „Kłosy” i in. ${ }^{14}$ Szczególnie aktywny w tej dziedzinie był tygodnik dla kobiet „Bluszcz”, który głównie poprzez artykuły jego redaktorki Marii Ilnickiej propagował m. in. freblizm ${ }^{15}$ czy też postulował rozszerzenie programu nauczania w prywatnych pensjach żeńskich, poprzez wprowadzenie wykładów z pedagogiki, psychologii i higieny ${ }^{16}$. W czasopismach takich, jak „Bluszcz”, a także „Nowe Tory”, „Dziecko” i „Ziemianka” ukazywały się sprawozdania z działalności ważnych towarzystw oświatowych, społecznych i naukowych związanych z wychowaniem przedszkolnym, np. Towarzystwa Wychowania Przedszkolnego, Towarzy-

${ }^{13}$ A. Cieszkowski, O ochronach wiejskich, „Biblioteka Warszawska” 1842, t. I, s. 367-412. Rozprawa ta ukazała się oddzielnie w wydaniu książkowym we Lwowie w roku 1845.

${ }^{14}$ Zob. wybrane artykuły, które pojawiły się w wyżej wymienionych pismach: H. Goldammer, Ogródek dziecięcy, „Opiekun Domowy” 1873, nr 40, s. 319; S. Miałkowski, Kwestia ogródków freblowskich u nas, „Bluszcz” 1868, nr 17, s. 101-102; A. Wiślicki, O metodzie Froebla, wprowadzonej do ochronki I, „Kłosy” 1868, nr 136, s. 79-85; Teatrzyk dziecinny w ochronce im. Ks. Boudouina, „Kronika Rodzinna” 1868/1869, nr 10, s. 160; Jeszcze kilka stów o metodzie Froebla, „Kronika Rodzinna” 1868/1869, nr 3, s. 42; A. Wiślicki, W sprawie ochron warszawskich, „Przegląd Tygodniowy”1869, nr 39, s. 325; A. Dygasiński, Kilka słów o wychowaniu fizycznym dzieci, „Niwa” 1887, z. 309, s. 847-855; M. Weryho, Zaklady freblowskie, „Kurier Warszawski" 1896, z dn. 7-8 II; M. Roszkowski, O potrzebie zaktadania u nas ochron dla dzieci, „Zdrowie” 1903, z. 6 i 7, s. 625-627; M. Laskowiczówna, Dom dziecięcy, „Ruch Pedagogiczny” 1912, nr 9, s. 116-119; A. Grudzieńska, Reforma ogródka dziecięcego, „Świat Kobiecy” 1906, nr 39, s. 406; M. Weryho, W sprawie ochroniarek, „Świat Kobiecy” 1905, nr 39, s. 455; Zjazd ochroniarek, „Prawda” 1906, nr 25, s. 301-302; J. Tyszkówna, Dom dziecięcy w Warszawie, „Dziecko” 1913, z. 8, s. 488-490; M.C.Z., Towarzystwo Wychowania Przedszkolnego, „Nowe Tory” 1909, t. I, s. 81-82; A. Załęska, Metoda Marii Montessori, „Ziemianka” 1913, t. II, s. 16.

${ }^{15}$ M. Ilnicka, Praca kobieca - bona, „Bluszcz” 1880, nr 44, s. 345-346.

${ }^{16}$ F. Łagowski, Kobiety nasze wobec pedagogiki, „Bluszcz” 1884, nr 37, s. 293, nr 38, s. 303. 
stwa Badań nad Dziećmi, Warszawskiego Towarzystwa Higienicznego, Polskiej Macierzy Szkolnej i Zjednoczonego Stowarzyszenia Ziemianek.

Wraz z aktywizacją działalności oświatowej ówczesnych pedagogów i psychologów na polu zagadnień przedszkolnych, wielu z nich zaczynało prowadzić również ożywioną działalność publicystyczną. Do takich postaci należy zaliczyć m. in. Marię Weryho-Radziwiłłowiczową, która publikowała artykuły poświęcone problematyce wychowania przedszkolnego początkowo $\mathrm{m}$. in. na łamach wspomnianego wcześniej „Bluszczu”, a następnie w „Przeglądzie Pedagogicznym", który odegrał najważniejszą rolę w tworzeniu typowego czasopiśmiennictwa dla wychowawczyń przedszkoli.

„Przegląd Pedagogiczny” w roku 1888 wprowadził na swoje łamy dział przedszkolny, który od roku 1891, jako dodatek specjalny do tego pisma, otrzymał nazwę - „Ogródek dziecięcy”. Dodatek ten był pierwowzorem późniejszych, samodzielnie funkcjonujących w okresie międzywojennym czasopism o tematyce przedszkolnej. Ukazywał się on od października $1891 \mathrm{r}$., $\mathrm{z}$ reguły raz w miesiącu i wychodził z przerwą półroczną w roku 1898, do roku 1903. W latach 1891-1898 redaktorem dodatku była M. Weryho, natomiast w latach 1898-1903 jej uczennica - Jadwiga Chrząszczewska. Wśród autorów publikujących na łamach „Ogródka dziecięcego” znaleźli się, obok Marii Weryho, Jadwigi Chrząszczewskiej, Anieli Szycównej, Izy Moszczeńskiej, również znani ówcześni lekarze, dietetycy i higieniści. Problematykę wychowania przedszkolnego, poza specjalistycznym „Ogródkiem dziecięcym”, poruszano również na łamach całego „Przeglądu Pedagogicznego”. Istniała wyraźna korelacja między problematyką ogólnoteoretyczną $\mathrm{z}$ zakresu pedagogiki przedszkolnej poruszanej w „Przeglądzie Pedagogicznym” z tematyką artykułów metodyczno-popularyzatorskich zamieszczonych $\mathrm{w}$ dodatku do danego numeru pisma. Problematykę przedszkolną podejmowano obszernie w działach: „Psychologia”, „Wychowanie fizyczne i moralne” oraz w „Poradniku wychowawcy”. Wzmożone zainteresowanie tą problematyką na łamach „Przeglądu Pedagogicznego" zauważyć można w numerach wydawanych w latach 1890-1898, kiedy to redaktorem pisma był znakomity psycholog i pedagog Jan Władysław Dawid, szczególnie zainteresowany wychowaniem małych dzieci. W tym samym okresie dodatek przedszkolny redagowała $\mathrm{M}$. Weryho, która wraz z odejściem J. W. Dawida ze stanowiska redaktora naczelnego również złożyła swoją rezygnację ${ }^{17}$. Działalność piśmiennicza $M$. Weryho nie ustała jednak z jej odejściem z „Przeglądu Pedagogicznego”. Zaczęła pisywać m. in. do feministycznego pisma „Świat Kobiecy”, w którym z czasem zainicjowała powstanie i objęła redakcję dodatku przedszkolnego zatytułowanego „Wskazówki dla

${ }^{17}$ B. Sandler, Wychowanie przedszkolne i kształcenie wychowawczyń w Królestwie Polskim, Wrocław-Warszawa-Kraków 1968, s. 105. 
wychowawczyń i ochroniarek ludowych"18. Dodatek od początku istnienia stawiał sobie ambitne zadania i wiernie je wypełniał. We wstępnym artykule do nowego działu M. Weryho pisała:

W chwili obecnej społeczeństwo nasze odczuwa bardziej niż kiedykolwiek potrzebę zakładania ochron wiejskich, prowadzonych przez osoby wykwalifikowane. Ze sprawą tą wiąże się potrzeba organu, który by te wychowawczynie dzieci wiejskich informował, zagrzewał do pracy i ciągłego postępu, a tym samym podnosił stanowisko ochron wiejskich, czyniąc je prawdziwymi zakładami wychowawczymi dla ludu. [...] Być może, w tej wspólnej pracy uda się nam posunąc sprawę ochron trochę naprzód, stworzyć typ ochronki polskiej, zastosowanej do warunków miejscowych i do natury naszych dzieci i otrząsnąc się z tych anachronizmów, które tamują wszelki postęp w ochronach ${ }^{19}$.

Dodatek ukazywał się niespełna rok, do grudnia roku 1906, kiedy zlikwidowano pismo „Świat Kobiecy”. Doświadczenia, jakie M. Weryho zdobyła redagując najpierw „Ogródek dziecięcy”, a następnie „Wskazówki dla wychowawczyń i ochroniarek ludowych", przyczyniły się do założenia przez nią już w wolnej Polsce typowego pierwszego czasopisma dla nauczycieli przedszkoli zatytułowanego „Wychowanie Przedszkolne”.

„Wychowanie Przedszkolne" było organem Towarzystwa Wychowania Przedszkolnego. Ukazywało się od stycznia 1925 do roku 1931 jako miesięcznik, a od 1931 do kwietnia 1939 r. jako dwumiesięcznik. Było najdłużej wydawanym periodykiem dotyczącym wychowania przedszkolnego w okresie II Rzeczypospolitej. Przez cały okres istnienia czasopismo to było redagowane przez M. Weryho. We wstępie do pierwszego numeru redakcja tak przedstawiła profil czasopisma:

Wychowanie przedszkolne jest u nas kopciuszkiem pedagogicznym. Społeczeństwo otacza szkołę należytą opieką - przedszkole natomiast jest w znacznie mniejszym stopniu przedmiotem troski ogólnej, jakkolwiek jest oczywiste znaczenie, jakie przedstawia ta dziedzina wychowawcza, jako podstawa i przygotowanie do pracy szkolnej. Niedość jest posiadać przedszkola i seminaria, trzeba myśleć i o wychowawczyniach, o dalszym ich rozwoju; trzeba umożliwić im zdobywanie nowego materiału myślowego, dostarczyć im wskazówek potrzebnych, uprzystępnić dostęp do nowych zdobyczy pedagogicznych $\mathrm{w}$ zakresie ich zawodu. W tym celu rozpoczynamy wydawnictwo pisma, na którego program będą się składały rzeczy następującej treści: artykuły treści naukowej i metodologicznej w zakresie pedagogiki, wskazówki, jak stosować pogadanki, opowiadania, gry, ćwiczenia zmysłów, roboty i inne zajęcia, ażeby je uczynić przyjemnymi i pożytecznymi, powiadamianie czytelników o stanie obecnym wychowania przedszkolnego w kraju i za granica, nawiązanie ścisłego związku pomiędzy wychowawczyniami i redakcją - zamieszczeniem ich pytań i odnośnych na nie odpowiedzi przez redakcję pisma (sprawozdania), oceną książek

${ }^{18}$ M. Weryho, Wskazówki dla wychowawczyń i ochroniarek ludowych, „Świat Kobiecy” 1905, nr 40, s. 470-471; nr 42, s. 494-495; nr 44/45, s. 522-523; nr 48/49, s. 554-555; nr 51, s. $578-579 ; 1906$, nr 1 s. $11-12$; nr 4, s. 38 ; nr 6, s. 62-63; nr 8, s. 86-87; nr 10, s. 111; nr 12, s. $135 ;$ nr 16 , s. 182,$183 ;$ nr 21, s. $242-243$.

${ }^{19}$ M. Weryho, W sprawie ochroniarek, „Świat Kobiecy” 1905, nr 39, s. 455. 
pedagogicznych i literatury dziecięcej. Nie mamy zamiaru krępować inicjatywy wychowawczyń przez narzucanie im gotowych schematów lub wzorów, przeciwnie - pismo będzie dążyć do tego, by młodym pracownikom dostarczyć materiału do własnej dalszej, samodzielnej przeróbki myślowej, do dania im możności zapoznania innych z wynikami ich własnej obserwacji.

Z gorącym życzeniem, aby pismo stało się jak najprędzej nicią łączącą rozproszone usiłowania wychowawczyń w jedną całość troski wspólnej o podniesienie poziomu wychowania przedszkolnego w Polsce oddajemy pismo - my - koleżanki starsze - naszym koleżankom młodszym ${ }^{20}$.

Komitetowi redakcyjnemu udało się pozyskać do współpracy wybitnych ludzi nauki, psychologów, pedagogów, lekarzy, działaczy społecznych, których rozprawy i artykuły pozwalały utrzymywać czasopismo na wysokim poziomie. Do grona autorów publikujących w „Wychowaniu Przedszkolnym” należeli m. in.: Maria Uklejska, Zofia Żukiewiczowa, Lucyna MolendzińskaWernerowa, Iza Moszczeńska, Wanda Krahelska-Mackiewicz, Wanda Daszewska, Maria Młodowska, Nina Bobieńska, Maria Gerson-Dąbrowska, Zofia Bogdanowiczowa, Maria Librachowa, Rafał Radziwiłłowicz, Janusz Korczak, Stefan Szuman i Władysław Sterling.

W lutym roku 1929 Związek Nauczycielstwa Przedszkoli w Polsce, rozpoczął wydawanie miesięcznika zatytułowanego "Zagadnienia Przedszkolne”. Redaktorem pisma został Julian Zarembski. Czasopismo ukazywało się do roku 1931. W roku 1933 czasopismo wznowiono jako kwartalnik, pod nieco zmienionym tytułem - „Zagadnienia Przedszkolne i Wychowawcze”, a redakcję objęła Zofia Witkowska. W roku 1934 pismo przemianowano na „Plan Prac w Przedszkolu" i jako organ Sekcji Pedagogicznej przy Związku Polskiego Nauczycielstwa Przedszkoli i Wychowawców ukazywało się do wybuchu II wojny światowej. Czasopismo to znacznie zmieniło się na przestrzeni owych 10 lat, z czasopisma zajmującego się głównie polityką oświatową przeobraziło się w poradnik typowo metodyczny.

Niewątpliwie jednym z ważniejszych czasopism poświęconych opiece i wychowaniu małego dziecka w II Rzeczpospolitej było założone przez Sekcję Wychowawczyń Przedszkoli Związku Nauczycielstwa Polskiego w roku 1933 pismo „Przedszkole”, pod redakcją Lucyny Sękowskiej. Tak redakcja przedstawiała nowe czasopismo we wrześniu 1933 r. we wstępie do pierwszego numeru

„Przedszkole” będzie dostarczało wiadomości o wszelkich zarządzeniach władz w dziedzinie przedszkolnej, będzie omawiało potrzeby przedszkoli społeczne i wychowawcze, ponadto będzie informowało o ruchu przedszkolnym w kraju i za granicą, tak pod względem organizacyjnym i pedagogicznym, jak też i zawodowym. Sprawom dotyczącym kształcenia i dokształcania personelu przedszkolnego, jego obowiązków służbowych i warunków pracy oraz działalności Sekcji Wychowawczyń Przedszkoli ZNP i jej oddziałów będzie przydzielone w naszym miesięczniku stałe miejsce. „Przedszkole” ma zapewnioną współpracę poważnych sił z dziedziny pedagogiki, higieny, liczy też na ścisły kontakt z fachowymi pracowniczkami przedszkoli we

\footnotetext{
${ }^{20}$ M. Weryho, Stowo wstępne, ,Wychowanie Przedszkolne” 1925, s. 1.
} 
wszystkich dzielnicach Polski. „Przedszkole” idzie w świat z wiarą, iż przysłuży się sprawie wychowania przedszkolnego oraz z nadzieją, że przyczyniając się do normowania i prostowania zasad wychowania dzieci polskich $\mathrm{w}$ początkowym stadium ich rozwoju, przyczyni się tym samym do budowy trwałej państwowości polskiej ${ }^{21}$.

W „Przedszkolu” artykuły zamieszczali wybitni przedstawiciele nauki, lekarze różnych specjalności, psychologowie i pionierki nowoczesnego ruchu wychowania przedszkolnego w Polsce. Do grona tego należeli m. in. Stefan Baley, Stefan Szuman, Sergiusz Hessen, Stefan Truchim, Maria GrzywakKaczyńska, Jan Bogdanowicz, Adam Charszewski, Zofia Żukiewiczowa i Zofia Bogdanowiczowa. W periodyku pojawiały się bardzo cenne artykuły dotyczące zdrowia, rozwoju psychicznego i fizycznego dzieci, bogaty był dział informacji o systemach i metodach wychowania przedszkolnego na świecie, związanych $\mathrm{z}$ ruchem Nowego Wychowania. Czasopismo wydawane było nieprzerwanie do roku 1939, jako miesięcznik do wakacji roku 1938, natomiast w roku szkolnym 1938/1939 już jako dwumiesięcznik.

W roku 1935 na przełomie października i listopada ukazało się kolejne czasopismo „Moje Dziecko”, będące, podobnie jak „Plan Prac w Przedszkolu” organem Związku Polskiego Nauczycielstwa Przedszkoli i Wychowawców. Redaktorem pisma została również Zofia Witkowska. W podtytule zamieszczono informację, że jest to miesięcznik dla rodziców i wychowawców. We wstępie w pierwszym numerze tego periodyku redakcja przedstawiła zamierzenia i cele, jakie stawia sobie wydając nowy periodyk. Czytamy w nim:

Słusznie uważa się dzieci za skarb narodu i słusznie czyni się robiąc wszystko, aby je dobrze wychować. Ale w tej trosce i pracy wychowawczej niedość bierze się pod uwagę dwa ogromnie ważne momenty sprawy, mianowicie: po pierwsze za mało uwzględnia się potrzeby wychowawcze wieku przedszkolnego, po drugie za mała jest współpraca czynnika rodzicielskiego, współpraca w kierunku czynienia zeń kontynuatora trosk, zabiegów i prac wychowania przedszkolnego, co sprawia, że czynnik ten bardzo często przekreśla dodatnie wyniki działalności wychowawczej przedszkoli.

Co do pierwszego momentu, to nie trzeba się silić na udowodnienie jego prawdziwości. Nikła liczba przedszkoli w stosunku do ilości dzieci w wieku przedszkolnym, ubogie ich wyposażenie i w ogóle traktowanie ich jako podrzędnego odcinka działalności wychowawczo-oświatowej, wszystko to są fakty aż nadto znane, abyśmy je mieli tu szczegółowo wymieniać. Zaznaczamy więc krótko, będziemy prowadzili akcję publicystyczną, mającą na celu zapewnienie wychowaniu przedszkolnemu pełnych praw obywatelskich. Co do drugiego momentu, to będziemy się starali dotrzeć do rodziców, nawiązać z nimi współpracę i wspólnie, po przyjacielsku, z jedyną troską o dobro dzieci, prowadzić dzieło wychowawcze wg naszego najlepszego rozumienia i wymagań ostatnich zdobyczy naukowych. Słowem pragniemy, aby wychowanie przedszkolne, jego troski, zabiegi i prace znalazły $w$ rodzicach, wychowawcach i przyjaciołach dzieci, dostatecznie energicznych, szczerych i umiejętnych działaczy ${ }^{22}$.

${ }^{21}$ L. Sękowska, Stowo wstępne, , Przedszkole” 1933, nr 1, s. 1.

${ }^{22}$ Z. Witkowska, Stowo wstęne, „Moje Dziecko” 1935, nr 1, s. 1. 
Od grudnia roku 1938 czasopismo, zachowując swój profil, stało się organem Towarzystwa Przyjaciół Przedszkoli, a nowym redaktorem został Jan Przegodnia Kryński.

Oprócz wyżej wymienionych czasopism poświęconych wychowaniu dzieci w wieku przedszkolnym, w okresie międzywojennym ukazało się jeszcze kilka innych tytułów, aczkolwiek były to już czasopisma efemeryczne. Do takich krótkotrwale wydawanych należą: „Sprawy Przedszkolne” firmowane przez Związek Zawodowy Ochroniarek i „Głos Wychowawcy” - czasopismo Związku Zawodowego Freblanek. Pierwsze z nich ukazało się w trzech numerach w roku 1922, drugie natomiast wydano jedynie raz, w grudniu 1932 r. Ponadto pojawiło się kilka regionalnych czasopism poruszających $\mathrm{m}$. in. problematykę przedszkolną: „Przyszłość Dziecka” - wydawane w roku 1933 w Wodzisławiu Śląskim, „Przyszłość” - ukazujące się w latach 1934-1936 w Pszczynie i „Szkolnictwo” - wydawane w Chełmnie w latach 1926-1928. Dwa tytuły publikowane były również przez mniejszości narodowe. W roku 1925 ukazało się w Warszawie kilka numerów żydowskiego czasopisma dotyczącego przedszkoli, które nosiło tytuł - „Gan Jełodim”, we Lwowie zaś od marca roku 1938 do czerwca roku 1939 wychodziło czasopismo przedszkolne zatytułowane „Ukrainske Doskillija”.

Czasopisma przedszkolne ukazujące się w okresie II Rzeczpospolitej reprezentowały wysoki poziom merytoryczny, były cenione przez ówczesnych pedagogów, psychologów zarówno teoretyków, jak i praktyków. Odegrały dużą rolę $\mathrm{W}$ popularyzowaniu myśli pedagogicznej, ponieważ były najbardziej dostępną formą przekazu dla dokształcających się nauczycieli. Dziś są świadectwem wysoko rozwiniętej teorii i praktyki wychowania przedszkolnego w Polsce międzywojennej i wciąż mogą stanowić inspirację dla współczesnego polskiego przedszkola. 